\title{
The effects of different electrolyte composition in dialysate on QTc interval; a controlled trial
}

\author{
Foroogh Sabzghabaei*, Seyed Alireza Heydariezade, Rashin S Joodat \\ ${ }^{1}$ Department of Medicine, Firoozgar Hospital, Iran University of Medical Sciences, Tehran, Iran
}

\section{A R T I C L E I N F O}

Article Type:

Original

Article History:

Received: 29 January 2016

Accepted: 5 April 2016

Published online: 6 April 2016

\section{Keywords:}

Hemodialysis

QT interval

Dialysate fluid

Cardiovascular disease

\begin{abstract}
A B S T RAC T
Introduction: Hemodialysis (HD) has impact on the cardiovascular system by inducing changes in the characteristics of body fluids such as $\mathrm{PH}$, temperature and electrolyte concentrations. In the previous studies, prolongation of the QT interval and increase of QT dispersion have been reported during HD sessions. These changes were more significant while using solutions with less potassium and higher bicarbonate during dialysis.

Objectives: The aim of our study was to investigate the effects of different potassium and bicarbonate concentrations on electrocardiography (ECG) parameters and the electrochemical balance of cell membranes.

Patients and Methods: This is a double blind controlled clinical trial with crossover design. This interventional study has been conducted on 36 patients over 18 years who undergoing HD 3 times a week for at least 6 months. Twelve-lead ECG has been obtained before starting and one hour after end of each HD session. The QTc was measured and changes recorded by a cardiologist. Correlations were evaluated by univariate regression analysis.

Results: 54.38 years (16 to 77 years), $66.7 \%$ were male. No significant increase in QT interval has been seen while dialyzing with $2 \mathrm{meq} / \mathrm{l}$ potassium and $24 \mathrm{meq} / \mathrm{l}$ bicarbonate, $2 \mathrm{meq} / \mathrm{l}$ potassium and $28 \mathrm{meq} / \mathrm{l}$ bicarbonate and $3 \mathrm{meq} / \mathrm{l}$ potassium and $24 \mathrm{meq} / \mathrm{l}$ bicarbonate beside high calcium (2.5 meq/l) dialysate was conducted. Age, gender, serum calcium and serum bicarbonate level before HD session did not influence the mean QT intervals before and after dialysis.

Conclusion: Concentration of potassium beside moderate dose of bicarbonate in dialysis bath had not any significant influence on QT intervals after dialysis.
\end{abstract}

Implication for health policy/practice/research/medical education:

Different concentration of potassium beside moderate dose of bicarbonate in dialysis bath had not any significant influence on QT intervals after dialysis.

Please cite this paper as: Sabzghabaei F, Heydariezade SA, Joodat RS. The effects of different electrolyte composition in dialysate on QTc interval; a controlled trial. J Renal Inj Prev. 2016;5(3):153-156. DOI: 10.15171/jrip.2016.32

\section{Introduction}

Risk of cardiovascular disease increases in end stage renal disease (ESRD) patients undergoing maintenance hemodialysis (HD). This increased risk is due to renal and extra-renal factors (1-3).

Moreover, in HD patients, high mortality rate is due to HD complications such as arrhythmia and sudden cardiac death during HD sessions $(2,3)$.

HD influences the cardiovascular system by inducing changes in the characteristics of body fluids, such as $\mathrm{PH}$, temperature and electrolyte concentrations (4).

Simple diffusion is the mechanism of removal of potassium during HD (5) and is determined by the blood-di- alysate concentration gradient, which generates diffusiveconvective flows through the HD membrane $(4,5)$. The use of dialysis baths with low potassium content presents a high gradient between plasma and HD bath which can lead to decrease plasma potassium levels. This can cause neural and skeletal muscle dysfunction $(6,7)$. Moreover, decreased potassium level in plasma can induce cardiac arrhythmias. Also, hypocalcemia is associated with an increase in action potential duration and QT interval prolongation (8). However, high concentration of potassium in the dialysis bath, decreases removal of potassium from plasma and makes HD less effective.

Electrocardiography (ECG) is used to detect arrhythmias 
such as SVPCs (supraventricular premature contractions) and PVCs (premature ventricular contractions), ST segment elevation, inverted $\mathrm{T}$ wave and atrial fibrillation (AF) which are reliable markers of the altered electric potential of the myocytes $(9,10)$. As mentioned before, HD alters the duration and homogeneity of ventricular repolarization. The QT interval and the QT interval corrected for heart rate (QTc) reflect the duration of ventricular depolarization and repolarization. Previous studies have shown that QTc is very sensitive to alterations in plasma potassium concentration and $\mathrm{PH}(11,12)$. QT dispersion (QTd) and QTc dispersion (QTcd) (defined as the difference between the maximal and minimal QT and QTc, respectively) represent the variability of cardiac repolarization, and they are found to be significantly prolonged during HD and are considered to be important markers of the risk of severe, even fatal cardiac arrhythmias $(11,12)$. In the previous studies, prolongation of the QT interval, (13-15) an increase of QT dispersion, (16-18) and an alteration of the capability to adapt QT interval to heart rate changes (19) have been reported during HD sessions.

A conducted study on $22 \mathrm{HD}$ patients in 2011, the influence of different concentrations of potassium (2 and 3 meq/l), calcium $(1.25,1.5$ and $1.75 \mathrm{meq} / \mathrm{l})$ and bicarbonate (30 and $34 \mathrm{meq} / \mathrm{l})$ in dialysate on QTc interval were tested. Results have shown that dialysis bath with less potassium, less calcium and highest concentration of bicarbonate causes significant increase in QTc. They concluded that electrolyte and bicarbonate concentrations in dialysate are important determinants of the QT duration (20). In a study by Genovesi et al in 2009, dialysis baths with different concentrations of potassium ( 2 and $3 \mathrm{meq} / \mathrm{l}$ ) and calcium $(1.25,1.5$ and $1.75 \mathrm{meq} / \mathrm{l})$ were tested on 16 patients. HD bath with less potassium, less calcium and highest bicarbonate concentrations made significant increase in QTc. They found that selection of HD bath must be done on the basis of QT interval before HD (21).

In the cohort study of Buemi et al in 2005, 28 patients underwent dialysis for 4 hours three times per week. First session performed with constant potassium concentration in HD bath and the next two sessions performed with increased and decreased potassium concentrations, respectively. ECGs were done at the start of dialysis (T0), at 15 (T15), 45 (T45), 90 (T90) and 120 minutes (T120) after the beginning of the session, and at the end of treatment (Tend). ECG-derived data (QT, QTd, QTc and QTcd) were calculated and intra- and extracellular potassium concentrated were measured. Highest QT dispersion was seen between 0 to 15 minutes and 15 to 45 minutes and QTc while dialyzing with low potassium HD bath concentration were significantly increased, while intracellular potassium level did not change. They noted that potassium concentration affects the electrical charge of most of the cells (22).

\section{Objectives}

The aim of our study was to investigate the effects of different potassium and bicarbonate concentrations on
ECG parameters and the electrochemical balance of cell membranes.

\section{Patients and Methods}

The study is a double blind controlled, crossover trial, on the effect of different dialysate composition on QT interval after HD.

Thirty-five patients older than 16 years who undergoing HD 4 hours three times per week for at least six months entered the study. None of the patients had dysrhythmias, heart failure, active coronary disease and use of antiarrhythmic drugs. HD was performed using a polysulfone membrane, blood flow rate was $300-350 \mathrm{cc} / \mathrm{min}$ and dialysate flow was $500-800 \mathrm{cc} / \mathrm{min}$. Dialysate water was purified by reverse osmosis. Each patient underwent a midweek HD session with four different dialysate compositions as follow, in four consecutive weeks. Twelve-lead ECG was recorded by CARWELL electrocardiogram before beginning and one hour after end of dialysis and QT was measured by a cardiologist ( who is uninformed about the HD solutions) in at least three leads and in three consecutive cardiac cycle and the average was recorded. QTc was calculated by Bazett's formula (QTc $=\mathrm{QT} / \sqrt{\mathrm{RR}})(11)$. A blood sample was taken before $\mathrm{HD}$ to evaluate serum calcium $(\mathrm{Ca})$ and bicarbonate.

Our HD solutions include

Solution no.1: $\mathrm{K}=2 \mathrm{meq} / \mathrm{l}, \mathrm{HCO} 3=24 \mathrm{meq} / \mathrm{l}, \mathrm{Na}=140$ $\mathrm{meq} / \mathrm{l}, \mathrm{Ca}=2.5 \mathrm{meq} / \mathrm{l}$

Solution no.2; K=2 meq/l, HCO3=28 meq $/ \mathrm{l}, \mathrm{Na}=140$ $\mathrm{meq} / \mathrm{l}, \mathrm{Ca}=2.5 \mathrm{meq} / \mathrm{l}$

Solution no.3; K=3 meq/l, HCO3=24 meq/l, Na=140 $\mathrm{meq} / \mathrm{l}, \mathrm{Ca}=2.5 \mathrm{meq} / \mathrm{l}$

Solution no.4; $\mathrm{K}=3 \mathrm{meq} / \mathrm{l}, \mathrm{HCO} 3=28 \mathrm{meq} / \mathrm{l}, \mathrm{Na}=140$ $\mathrm{meq} / \mathrm{l}, \mathrm{Ca}=2.5 \mathrm{meq} / \mathrm{l}$, which were used respectively.

\section{Ethical issues}

1) The research followed the tenets of the Declaration of Helsinki; 2) informed consent was obtained, and they were free to leave the study at any time and 3) the research was approved by the ethical committee of Iran University of Medical Sciences by number; 93/D/105/2128. Registration code in Iran Registry of Clinical Trials is IRCT2013021011194N3 (http://www.irct.ir/).

\section{Statistical analysis}

The results are reported as means \pm standard deviation. Student's $t$ test was used. Changes in QTc intervals were evaluated by repeated measures. Correlations were evaluated by univariate regression analysis. The $P$ value less than 0.05 was considered statistically significant.

\section{Results}

Mean $( \pm$ SD) age of patients was $54.38( \pm 15)$ years (16 to 77 years), $66.7 \%$ were male. The baseline laboratory variables of patients are illustrated in Table 1.

The changes induced in QTc intervals by different dialysate concentration of $\mathrm{K}$ and bicarbonate are shown in Table 2. 
There is no significant change in QTc interval after dialysis in any of dialysis solutions. Longest QTc interval was recorded after dialysis with the third solution (446.97 \pm 34.02$)$ and shortest QTc interval was recorded after dialysis with the first solution $(434.99 \pm 41.76 \mathrm{~ms})$. The mean differences between QTcs after and before dialysis were $4.96 \pm 32.22,8.1 \pm 39.44,6.5 \pm 32.55$ and $1.91 \pm 39.2$, for solutions number $1,2,3,4$ respectively, and there was not any significant difference between them. Long QTc after dialysis (QTc > $440 \mathrm{~ms}$ ) were seen in 61\%, $50 \%, 58 \%$ and $38 \%$ for dialysate number $1,2,3$ and 4 , respectively.

Comparing mean QTc intervals after dialysis, the only significant difference was seen in comparison of third and fourth solution ( $\mathrm{P}=0.03$; Table 3$)$.

Age and gender had not caused any significant correlation with QT intervals before and after dialysis $(P=0.531$ and $P=0.78$, respectively).

Serum bicarbonate level before dialysis had not significant influence on the mean QT interval before and after dialysis $(P=0.758)$.

Table 1. Demographic and laboratory characters of patients

\begin{tabular}{lc}
\hline Number & 36 \\
\hline Male (\%) & $66.7 \%$ \\
Mean age (years) & $54.38 \pm 15$ \\
Serum bicarbonate (meq/L) & $21.71 \pm 4.74$ \\
Serum calcium (meq/L) & $8.75 \pm 1.04$ \\
Dialysis adequacy (KT/V) & $1.37 \pm 0.45$ \\
\hline
\end{tabular}

Table 2. QTC intervals by different composition dialysate

\begin{tabular}{lccc}
\hline \multirow{2}{*}{ Dialysate } & Mean QTC & Mean QTC & \multirow{2}{*}{ P } \\
\cline { 2 - 3 } & Before dialysis & After dialysis & \\
\hline No 1 & $434.50 \pm 29.64$ & $434.99 \pm 43.84$ & 0.946 \\
No 2 & $428.74 \pm 45.71$ & $436.85 \pm 32.53$ & 0.226 \\
No 3 & $440.47 \pm 45.71$ & $446.97 \pm 34.02$ & 0.239 \\
No 4 & $437.28 \pm 43.84$ & $435.99 \pm 83.8$ & 0.771 \\
\hline
\end{tabular}

Dialysate No 1: $\mathrm{K}=2 \mathrm{meq} / \mathrm{L}$, bicarbonate $=24 \mathrm{meq} / \mathrm{L}, \mathrm{Ca}=2.5 \mathrm{meq} / \mathrm{L}$; Dialysate No 2: $\mathrm{K}=2 \mathrm{meq} / \mathrm{L}$, bicarbonate $=28 \mathrm{meq} / \mathrm{L}, \mathrm{Ca}=2.5 \mathrm{meq} / \mathrm{L}$; Dialysate No 3: $\mathrm{K}=3 \mathrm{meq} / \mathrm{L}$, bicarbonate $=24 \mathrm{meq} / \mathrm{L}, \mathrm{Ca}=2.5 \mathrm{meq} / \mathrm{L}$; Dialysate No 4: K=3 meq/L, bicarbonate $=28 \mathrm{meq} / \mathrm{L}, \mathrm{Ca}=2.5 \mathrm{meq} / \mathrm{L}$.

Table 3. Comparison of mean QT intervals after dialysis with four different solutions

\begin{tabular}{lcccc}
\hline QTc (I) & QTc (J) & Mean Difference (J)-(I) & SE & P value \\
\hline \multirow{2}{*}{1} & 2 & -1.863 & 6.982 & 0.791 \\
& 3 & -11.988 & 6.911 & 0.092 \\
& 4 & -0.376 & 7.779 & 0.962 \\
& 1 & 1.863 & 6.982 & 0.791 \\
2 & 3 & -10.125 & 5.475 & 0.073 \\
& 4 & 1.486 & 6.784 & 0.828 \\
& 1 & 11.988 & 6.911 & 0.092 \\
3 & 2 & 10.125 & 5.475 & 0.073 \\
& 4 & 11.611 & 5.114 & 0.030 \\
& 1 & 0.376 & 7.779 & 0.962 \\
4 & 2 & -1.486 & 6.784 & 0.828 \\
& 3 & -11.611 & 5.114 & 0.030 \\
\hline
\end{tabular}

Abbreviation: $\mathrm{SE}$, standard error.

\section{Discussion}

HD appears to cause ECG changes which frequently occur after the start of an HD session, and persist for at least 5 hours after dialysis. These changes appear to have different causes, including dialysis-induced electrolyte alterations (9).

Although the effect of low plasma concentration of potassium and calcium on prolongation of ventricular repolarization has been proven (22), there is controversies about the role of dialysate concentration of potassium $(\mathrm{K})$, calcium $(\mathrm{Ca})$ and bicarbonate on QT interval.

Di Iorio et al studied $22 \mathrm{HD}$ patients with different dialysate bath concentrations of $\mathrm{K}, \mathrm{Ca}$ and bicarbonate and concluded that the effect of dialysis on QTc appears at the end of dialysis and remains up to 4 hours and mean absolute increase in QTc was observed with dialysate containing $\mathrm{Ca}=1.25 \mathrm{meq} / \mathrm{l}$ and bicarbonate $34 \mathrm{meq} / \mathrm{l}$ whatever the concentration of $\mathrm{K}$ was (20).

In the study by Genovesi et al on $16 \mathrm{HD}$ patients, they demonstrated that longest QTcs were seen with low K (2 $\mathrm{meq} / \mathrm{l})$ and low $\mathrm{Ca}(2.5 \mathrm{meq} / \mathrm{l})$ dialysis bath (19). Buemi et al examined two concentrations of $\mathrm{K}$ in dialysate, fix $\mathrm{K}$ concentration and flexible $\mathrm{K}$ with no more than $1 \mathrm{meq} / \mathrm{l}$ less than serum $\mathrm{K}$. They concluded that low $\mathrm{K}$ gradient between serum and dialysate has a protective role for prolonged repolarization after HD (22).

In our study there is not any significant prolongation of QTc interval after dialysis with different concentrations of $\mathrm{K}$ and bicarbonate. It is in contrast to findings of two previous mentioned studies. They noted that the effect of serum $\mathrm{K}$ and $\mathrm{Ca}$ is more important than dialysate in QTc interval after dialysis $(15,23,24)$.

In single study for evaluation of the effect of dialysate bicarbonate concentration, there was significant difference between bicarbonate 30 and $34 \mathrm{meq} / \mathrm{l}$ (22). We evaluated the effect of two different lower concentrations of bicarbonate (24 and $28 \mathrm{meq} / \mathrm{l})$ and it seems that at this level of bicarbonate in dialysate, QTc was not influenced significantly. This low level of bicarbonate in dialysate may have protective role for inducing QT prolongation and arrhythmia after dialysis.

\section{Conclusion}

In conclusion, dialysate with different concentration of $\mathrm{K}$ with bicarbonate up to $28 \mathrm{meq} / \mathrm{l}$ do not prolong QTc interval after dialysis significantly. Low bicarbonate may have a protective role for QT interval prolongation and arrhythmia after dialysis.

\section{Limitations of the study}

Despite using strict inclusion criteria, the present study has some limitations. The sample size was small and potential confounders such as $\mathrm{Ca}, \mathrm{K}$, and bicarbonate after dialysis were not evaluated. However this study had a crossover design and every patient had control of himself or herself, so the small number of patients in the study was not influenced the final results. However, a large study aimed at assessing the impact of dialysate electrolyte and 
serum electrolyte concentrations before and after dialysis on QTc interval and consequent risk of arrhythmias is essential.

\section{Authors' contribution}

FS; study design, preparation of manuscript, final revision and data interpretation. SAH; data gathering and manuscript edition. RSJ; data interpretation and manuscript preparation.

\section{Conflicts of interest}

The authors declared no competing interests.

\section{Ethical considerations}

Ethical issues (including plagiarism, data fabrication, double publication) have been completely observed by the authors.

\section{Funding/Support}

This research project was approved by Deputy for Research of Iran University of Medical Science the number of this project is 1390. This project started at September 1, 2014 and finished at February 10, 2015.

\section{References}

1. Foley RN, Parfrey PS, Sarnak MJ. Clinical epidemiology of cardiovascular disease in chronic renal disease. Am J Kidney Dis. 1998;32:S112-9. doi: 10.1053/ajkd.1998.v32. pm9820470.

2. Karnik JA, Young BS, Lew NL, Herget M, Dubinsky C, Lazarus JM, et al. Cardiac arrest and sudden death in dialysis units. Kidney Int. 2001;60:350-7. doi: 10.1046/j.15231755.2001.00806.x

3. Zebe H. Atrial fibrillation in dialysis patients. Nephrol Dial Transplant. 2000; 15:765-8. doi: 10.1093/ndt/15.6.765

4. Sforzini S, Latini R, Mingardi G, Vincenti A, RedaelliB. Ventricular arrhythmias and four-year mortality in haemodialysis patients. Gruppo Emodialisi e Patologie Cardiovascolari. Lancet. 1992;339:212-3.

5. Rombola G, Colussi G, De Ferrari ME, Frontini A, Minetti L. Cardiac arrhythmias and electrolyte changes during haemodialysis. Nephrol Dial Transplant. 1992; 7:318-22.

6. Fozzard HA. Excitable membranes. In: Seldin DW, Giebisch G, eds The Kidney. New York: Raven Press; 1985:229-262.

7. Knochel JP. Potassium gradients and neuromuscular excitability. In: Seldin DW, Giebisch G, eds. The Kidney: Physiology and Pathophysiology. Raven Press, New York: Raven Press; 1985:1207-1221.

8. Ter Keurs HE, Boyden PA. Calcium and arrhythmogenesis. Physiol Rev 2007;87:457-506. doi: 10.1152/ physrev.00011.2006

9. Abe S, Yoshizawa M, Nakanishi N, Yazawa T, Yokota $\mathrm{K}$, Honda $\mathrm{M}$, et al. Lectrocardiographic abnormalities in patients receiving hemodialysis. Am Heart J. 1996; 131:1137-44. doi: 10.1016/s0002-8703(96)90088-5.

10. Morales MA, Gremigni C, Dattolo P, Piacenti M, Cerrai T, Fazi A, et al. Signal-averaged ECG abnormalities in haemodialysis patients. Role of dialysis. Nephrol Dial Transplant. 1998;13:668-73. doi: 10.1016/s00028703(96)90088-5.

11. Beaubien ER, Pylypchuk GB, Akhtar J, Biem HJ. Value of corrected QT interval dispersion in identifying patients initiating dialysis at increased risk of total and cardiovascular mortality. Am J Kidney Dis. 2002; 39:83442. doi: 10.1053/ajkd.2002.32005

12. Nappi SE, Virtanen VK, Saha HH, Mustonen JT, Pasternack AI. QTc dispersion increases during hemodialysis with low-calcium dialysate. Kidney Int. 2000; 57:2117-22. doi: 10.1046/j.1523-1755.2000.00062.x

13. Maule S, Veglio M, Mecca F, Calvo C, Martina G, Marangella $\mathrm{M}$, et al. Autonomic neuropathy and QT interval in haemodialysed patients. Clin Auton Res. 2004;14:233-9.

14. Suzuki R, Tsumura K, Inoue T, Kishimoto H, Morii H. QT interval prolongationin the patients receiving maintenance haemodialysis. Clin Nephrol. 1998;49:240-4.

15. Covic A, Diaconita M, Gusbeth-Tatomir P, Covic M, Botezan A, Ungureanu G, et al. Haemodialysis increases QT(c) interval but notQT(c) dispersion in ESRD patients without manifest cardiac disease. Nephrol Dial Transplant. 2002;17:2170-7. doi: 10.1093/ndt/17.12.2170

16. Lorincz I, Matyus J, Zilahi Z, Kun C, Karanyi Z, Kakuk G. QT dispersion inpatients with end-stage renal failure and during hemodialysis. J Am Soc Nephrol 1999; 10:1297-302.

17. Cupisti A, Galetta F, Morelli E, Tintori G, Sibilia G, Meola $\mathrm{M}$, et al. Effect of haemodialysis on the dispersion of the QTc interval. Nephron. 1998;78:429-32. doi: 10.1159/000044972

18. Morris ST, Galiatsou E, Stewart GA, Rodger RS, Jardine AG. QT dispersion before and after haemodialysis. J Am Soc Nephrol. 1999;10:160-3.

19. Genovesi S, Rivera R, Fabbrini P, Dossi C, Bonforte G, Mircoli L, et al. Dynamic QT interval analysis in uraemic patients receiving chronic haemodialysis. J Hypertens. 2003;21:1921-6. doi: 10.1159/000044972.

20. Di Iorio B, Torraca S, Piscopo C, Sirico ML, Di Micco L, Pota A, et al. Dialysate bath and QTc interval in patients on chronic maintenance hemodialysis: pilot study of single dialysis effects. J Nephrol. 2012;25:653-60.

21. Genovesi S, Dossi C, Viganò MR, Galbiati E, Prolo F, Stella A, et al. Electrolyte concentration during hemodialysis and QT interval prolongation in uraemic patients. Europace. 2008;10:771-7. doi: 10.1093/europace/eun028

22. Buemi M, Aloisi E, Coppolino G, et al. The effect of two different protocols of potassium haemodiafiltration on QT dispersion. Nephrol Dial Transplant. 2005; 20:1148-54. doi: $10.1093 / \mathrm{ndt} / \mathrm{gfh} 770$

23. Khosoosi Niaki M, Saravi M, Oliaee F, et al. Changes in QT interval before and after hemodialysis. Caspian J Intern Med. 2013;4:590-4.

24. Howse M, Sastry S, Bell GM. Changes in the corrected QT interval and corrected QTdispersion during haemodialysis. Postgrad Med J 2002;78:273-5. doi: 10.1136/pmj.78.919.273

Copyright (C) 2016 The Author(s); Published by Nickan Research Institute. This is an open-access article distributed under the terms of the Creative Commons Attribution License (http://creativecommons.org/licenses/by/4.0), which permits unrestricted use, distribution, and reproduction in any medium, provided the original work is properly cited. 